\title{
Pengaruh Pemberian Temulawak (Curcuma xhanthorrhiza) terhadap Pertambahan Bobot Badan Kambing di Desa Sukaresik, Kecamatan Sindangkasih, Kabupaten Ciamis
}

\section{Yosa Atifah $^{1^{*}, \text { Dyah Gandasari }}{ }^{2}$ Harry $^{3}$}

${ }^{1}$ Penyuluhan Peternakan dan Kesejahteraan Hewan, Peternakan, Politeknik Pembangunan Pertanian Bogor ${ }^{2}$ Penyuluhan Peternakan dan Kesejahteraan Hewan, Peternakan, Politeknik Pembangunan Pertanian Bogor ${ }^{3}$ Penyuluhan Peternakan dan Kesejahteraan Hewan, Peternakan, Politeknik Pembangunan Pertanian Bogor

\begin{tabular}{l}
\hline \multicolumn{1}{c}{ ARTIKEL INFO } \\
\hline Sejarah artikel \\
Diterima $12 / 10 / 2021$ \\
Diterima dalam bentuk revisi 17/12/2021 \\
Diterima dan disetujui 23/12/2021 \\
Tersedia online 31/12/2021 \\
\hline Kata kunci \\
Feed additive \\
Inovasi pakan \\
Produktivitas ternak \\
\hline
\end{tabular}

\begin{abstract}
ABSTRAK
Populasi kambing di Desa Sindangkasih pada tahun 2020 adalah 1135 ekor. Jumlah tersebut sangat potensial untuk ditingkatkan kembali dengan cara memanipulasi pakan. Salah satu teknik manipulasi pakan yang dapat dilakukan adalah dengan pemberian tepung temulawak. Penelitian bertujuan untuk menganalisis pengaruh pemberian tepung temulawak terhadap pertambahan bobot badan ternak kambing dan menganalisis usaha penggemukan ternak kambing yang diberi tepung temulawak. Materi yang digunakan adalah kambing lokal dengan rataan bobot badan awal 20,5 kg. Metode penelitian menggunakan kaji terap 2 perlakuan yaitu $\mathrm{P} 0=$ kontrol dan $\mathrm{P} 1=$ kontrol + tepung temulawak 12 gr/ekor $+40 \mathrm{ml}$ air. Peubah yang diukur dalam kaji terap adalah pertambahan bobot badan harian $(\mathrm{PBBH})$. Peubah analisis usaha yang dihitung diantaranya pendapatan, $\mathrm{B} / \mathrm{C}$ ratio, $\mathrm{R} / \mathrm{C}$ ratio, BEP harga, BEP Produksi dan Marginal Benefit Cost Ratio (MBCR). Data dianalisis menggunakan Independent ttest. Data analisis usaha dianalisis secara deskriptif. Hasil kaji terap yang dilakukan pada ternak kambing menunjukkan terdapat perbedaan yang nyata dengan pemberian tepung temulawak terhadap PBBH. Hasil analisis usaha pada kedua perlakuan menunjukkan untuk perlakuan P1 lebih menguntungkan peternak dengan pendapatan $\mathrm{Rp}$ 1.329.145. Nilai $R / C$ ratio dan $B / C$ ratio paling tinggi pada $P 1$ dan nilai MBCR sebesar 23,132. Secara finansial pendapatan paling tinggi yaitu pada P1 dengan pemberian tepung temulawak 12 $\mathrm{gr}+40 \mathrm{ml}$ air, artinya pemberian tepung temulawak mampu memeningkatkan bobot badan kambing dan pendapatan peternak di Desa Sukaresik.
\end{abstract}




\section{ABSTRACT}

The population of goats in Sukaresik Village in 2020 was 1135 heads. This amount has the potential to be increased again by manipulating the feed. One of the feed manipulation techniques that can be done is by giving ginger flour. This study aims to analyze the effect of giving temulawak flour to the body weight gain of goats and to analyze the fattening business of goats fed with temulawak flour. The material used is a local goat with an average initial body weight of $20.5 \mathrm{~kg}$. The research method used an applied review of 2 treatments, namely $P O=$ control and $P 1$ $=$ control + ginger flour $12 \mathrm{~g} / \mathrm{head}+40 \mathrm{ml}$ of water . The variable measured in the applied study was daily body weight gain (PBBH). The business analysis variables that are calculated include income, $B / C$ ratio, $R / C$ ratio, price $B E P$, Production $B E P$ and Marginal Benefit Cost Ratio (MBCR). Data were analyzed using Independent t-test. Business analysis data were analyzed descriptively. The results of the applied study carried out on goats

\section{PENDAHULUAN}

Salah satu keberhasilan dalam pemeliharaan ternak kambing yaitu terletak pada pakannya. Pakan yang diberikan jangan sekedar dimaksudkan untuk mengatasi lapar atau sebagai pengisi perut saja melainkan harus benar-benar bermanfaat untuk kebutuhan hidup, membentuk sel-sel baru, mengganti selsel yang rusak dan untuk produksi (Widayati \& Widalestari 1996). Bahan pakan harus menyediakan zat-zat makanan yang dapat digunakan untuk membangun dan menggantikan bagian-bagian tubuh dan menciptakan hasil produksinya, seperti daging dan wol. Bahan pakan harus pula memberikan energi untuk keperluan proses tersebut (Anggorodi, 1985). Pakan yang berkualitas serta tidak hanya memberi single pakan (rumput) saja dapat mempengaruhi produktivitas ternak kambing. Pakan tambahan (feed additive) sangat berpengaruh penting terhadap pertambahan bobot badan harian showed that there was a significant difference with the provision of temulawak flour to PBBH. The results of the business analysis in both treatments showed that the P1 treatment was more profitable for farmers with an income of IDR 1,329,145. The highest $R / C$ ratio and $B / C$ ratio values were at $P 1$ and the MBCR value was 23,132. Financially, the highest income was in P1 with the provision of $12 \mathrm{~g}$ of temulawak flour $+40 \mathrm{ml}$ of water, meaning that the provision of temulawak flour was able to increase the body weight of goats and the income of farmers in Sukaresik Village.used, unfamiliar terms are italicized. Abstracts containing $200-250$ word of indonesian and english language using Times New Roman 10 points, space 1. Abstract contains: introduction (1-2 sentences), research objectives (1 sentence), materials and methods (3-5 sentences), research results (3- 5 sentences), sentences (1 sentence) made in 1 (one) paragraph.

(PBBH) ternak kambing. Hartadi \& Tillman (1991) mengatakan feed additive merupakan suatu bahan atau kombinasi bahan yang ditambahkan, biasanya dalam kuantitas yang kecil yang ditambahkan dalam ransum makanan ternak.

Feed additive yang berasal dari tanaman herbal belum banyak digunakan oleh peternak dalam mengobati hewan ternaknya. Pemakaian tanaman herbal sangat aman digunakan untuk ternak dibandingkan obatobatan kimia, karena dapat memperkecil keberadaan zat cemaran dalam tubuh ternak (Kartika, 2017).

Tanaman herbal bisa dijadikan pakan tambahan untuk ternak dengan mencampurkannya pada air minum atau bisa diminumkan langsung pada ternak. Salah satu jenis tanaman herbal yang berpotensi untuk dikembangkan adalah temulawak. Temulawak merupakan jenis herbal yang mudah ditemukan 
di Desa Sukaresik, Kecamatan Sindangkasih, Kabupaten Ciamis.

Temulawak merupakan jenis temutemuan yang mengandung minyak atsiri dan kurkumin, minyak atsiri memiliki fungsi untuk mencerna bahan kimia beracun dalam tubuh sedangkan kurkumin sendiri bermanfaat sebagai zat yang dapat membangkitkan nafsu makan (Kartika, 2017).

Pemanfaatan temulawak yang digunakan sebagai obat herbal untuk menambahkan nafsu makan ternak kambing merupakan salah satu inovasi pakan tambahan (feed additive) yang dapat diadopsi peternak dalam upaya meningkatkan produktivitas melalui peningkatan bobot badan.

Kecamatan Sindangkasih merupakan salah satu kecamatan yang berada di wilayah binaan BPP Sindangkasih. Usaha ternak kambing di Kecamatan Sindangkasih mempunyai populasi mencapai 1135 ekor kambing. Jumlah tersebut menunjukkan usaha ternak kambing di Kecamatan Sindangkasih sangat berpotensi untuk dikembangkan. Faktor lingkungan dan sumber daya alam yang mendukung dalam kegiatan usaha peternakan kambing serta sumber daya manusia yang tersedia, merupakan modal untuk memulai usaha ternak kambing.

Tujuan yang hendak dicapai dalam penelitian di Kecamatan Sindangkasih adalah 1) Mengidentifikasi pertambahan bobot badan ternak kambing dengan pemberian temulawak sebagai pakan tambahan (feed additive). 2) Mengidentifikasi tingkat pendapatan usaha ternak kambing dengan pemberian Temulawak sebagai feed additive pada kambing.

\section{METODE}

\section{Alat dan Bahan}

Ternak yang digunakan yaitu 10 ekor Kambing Jawarandu jantan dengan bobot badan $\pm 20 \mathrm{~kg}$ yang berumur 8-12 bulan. Pakan yang diberikan adalah rumput lapang dan temulawak sebagai feed additive. Alat dan bahan lainnya yang digunakan diantaranya peralatan kandang seperti timbangan digital, timbangan gantung, dan spuit.

\section{Metode}

\section{Teknis}

Kaji terap dilaksanakan di Desa Sukaresik Kecamatan Sindangkasih Kabupaten Ciamis.

1. Kaji terap dilaksanakan selama 40 hari

2. Perlakuan menggunakan 10 ekor kambing Jawarandu jantan berumur 8-12 bulan, 5 ekor untuk perlakuan pemberian temulawak dan 5 ekor tanpa pemberian temulawak (kontrol).

3. Seluruh kambing yang dipakai untuk kaji terap diberi obat cacing berspektrum luas (Wormzol-k) seminggu sebelum dilaksanakan kaji terap.

4. Frekuensi pemberian temulawak 1 kali sehari pada minggu pertama, pada minggu selanjutnya diberikan 2 kali seminggu.

5. Pemberian tepung temulawak 12 gram yang ditambahkan dengan $40 \mathrm{ml}$ air.

6. Penimbangan bobot badan kambing dilakukan pada awal kaji terap dilaksanakan dan penimbangan selanjutnya dilakukan pada akhir perlakuan.

7. Untuk mengetahui keberhasilan hasil kaji terap digunakan uji $t$. 


\section{Peubah yang diamati dalam kaji terap}

Pertambahan Bobot Badan Harian (PBBH)

Kaji Terap adalah metode penyuluhan pertanian untuk meningkatkan kemampuan petani dalam memilih paket teknologi usaha tani yang telah direkomendasikan sebelum didemonstrasikan dan atau dianjurkan adalah kontak tani nelayan yang dilakukan di lahan usaha tani nelayannya dengan bimbingan penyuluh pertanian (Deptan, 2003).

Data pengambilan bobot badan diperoleh dari hasil penimbangan domba selama masa percobaan berlangsung. Penimbangan dilakukan pada awal dan akhir kaji terap dilaksanakan. Pertambahan Bobot Badan Harian (PBBH) dihitung dengan menggunakan rumus sebagai berikut:

PBBH $($ gr/ekor/hari $)=$ Bobot Akhir-Bobot Awal

\section{Analisis usaha}

Menurut Boesono et al. (2011) bahwa Analisis usaha merupakan suatu cara untuk mengetahui tingkat kelayakan dari suatu jenis usaha. Tujuan analisis usaha adalah mengetahui tingkat keuntungan dan pengemballian investasi. Analisis usaha dilakukan untuk mengetahui kelayakan usaha yang dijalankan. Menurut Soekartawi (2006) dalam Marianto, ada beberapa indikator yang bias digunakan untuk mengukur analisis usaha diantaranya adalah Break Event Point (BEP), Revenue Cost ratio (R/C ratio) dan Benefit Cost Ratio (B/C ratio) sedangkan menurut Malian (2004) menggunakan Marginal Benefit Cost Ratio (MBCR).
- BEP Produksi $(\mathrm{kg})=\frac{\text { Jumlah Input }}{\text { Jumlah Output }} \mathrm{x}$ produksi

- BEP Harga $(\mathrm{Rp})=\frac{\text { Jumlah Input }}{\text { Jumlah Output }} \quad \mathrm{x}$ harga

- $\mathrm{R} / \mathrm{C}$ ratio $=\frac{\text { Penerimaan }}{\text { Total Biaya Produksi }}$

- $\mathrm{B} / \mathrm{C}$ ratio

$$
=\frac{\text { Pendapatan }}{\text { Total Biaya Produksi }}
$$

- $\quad \mathrm{MBCR}$

Penerimaan Kotor $(B)-$ Pendapatan Kotor $(P)$ Total Biaya $(B)-$ Total Biaya $(P)$

\section{HASIL DAN PEMBAHASAN}

\section{Kaji Terap}

Adapun hasil kegiatan kaji terap yang telah dilaksanakan mendapatkan hasil rata-rata PBBH ternak kambing yang dapat dilihat pada Tabel 1.

Tabel 1. Hasil penimbangan kaji terap

\begin{tabular}{|c|c|c|c|c|c|}
\hline $\begin{array}{l}\text { Perla } \\
\text { kuan }\end{array}$ & $\begin{array}{l}\text { Ulan } \\
\text { gan }\end{array}$ & $\begin{array}{l}\text { Bera } \\
\mathbf{t} \\
\text { awal } \\
(\mathbf{k g})\end{array}$ & $\begin{array}{l}\text { Bera } \\
\text { t } \\
\text { akhi } \\
\text { r } \\
(\mathbf{k g})\end{array}$ & $\begin{array}{l}\text { BB } \\
\text { (kg } \\
\text { ) }\end{array}$ & $\begin{array}{l}\text { PBBH } \\
(\mathrm{kg})\end{array}$ \\
\hline \multirow{5}{*}{ P0 } & U1 & 20,5 & 23,5 & 3 & 0,0625 \\
\hline & U2 & 19 & 22,5 & 3,5 & 0,075 \\
\hline & U3 & 21 & 24 & 3 & 0,05 \\
\hline & U4 & 20,5 & 23,5 & 3 & 0,05 \\
\hline & U5 & 20 & 23 & 3 & 0,05 \\
\hline Jumlah & & 101 & 116,5 & $\begin{array}{l}15, \\
5\end{array}$ & 0,3875 \\
\hline Rata-rata & & 20,5 & 23,3 & 3,1 & 0,0775 \\
\hline \multirow{5}{*}{ P1 } & U1 & 18,5 & 3,5 & & 0,125 \\
\hline & U2 & 20 & 5 & & 0,125 \\
\hline & U3 & 25 & 9 & & 0,1 \\
\hline & U4 & 22 & 5 & & 0,075 \\
\hline & U5 & 20 & 3 & & 0,075 \\
\hline Jumlah & & 105 & 125 & 20 & 0,5 \\
\hline Rata-rata & & 21 & 25 & 4 & 0,1 \\
\hline
\end{tabular}

Sumber : Data primer diolah 2021

Tabel 1 menunjukkan rata-rata Pertambahan Bobot Badan Harian (PBBH) P0 yaitu $0,0775 \mathrm{~kg} / \mathrm{ekor} / \mathrm{hari}$, sedangkan rata-rata PBBH P1 yaitu $0,1 \mathrm{~kg} / \mathrm{ekor} / \mathrm{hari}$. $\mathrm{PBBH}$ tertinggi diperoleh $\mathrm{P} 1$ yang diberikan tepung 
temulawak $12 \mathrm{gr}+40 \mathrm{ml}$ air dengan peningkatan bobot badan mencapai $0,1 \mathrm{~kg} / \mathrm{ekor} / \mathrm{hari}$.

Dari hasil analisis PBBH hasil kaji terap menggunakan independent $t$-test menggunakan SPSS 21 maka didapatkan nilai $\mathrm{p}$ value P0 sebesar 0,008 dan P1 0,015 di mana <0,05 maka terlihat adanya perbedaan bermakna secara statistik atau signifikan dari probabilitas 5\%.

Berdasarkan penelitian sebelumnya Nizma et al. (2015), bahwa pemberian pakan tambahan berupa temulawak dapat memberikan pengaruh terhadap pertambahan bobot badan domba. Hasil penelitian menunjukkan rata-rata pertambahan berat badan pada hari ke 15 dan 30 pada perlakuan $\mathrm{P} 0, \mathrm{P} 1$ dan $\mathrm{P} 2$ yang dapat dilihat pada Tabel 2.

Tabel 2. Hasil Jurnal Penelitian Nizma

\begin{tabular}{lcc}
\hline \multicolumn{3}{c}{ Hari ke-15 } \\
\hline Perlakuan & Rataan $(\mathbf{K g})$ & PBBH $($ gr $)$ \\
P0 & $0,88^{\mathrm{a}}$ & 62,67 \\
P1 & $2,00^{\mathrm{a}}$ & 66,67 \\
P2 & $4,00^{\mathrm{b}}$ & 133,3 \\
\hline \multicolumn{3}{c}{ Hari ke-30 } \\
\hline Perlakuan & Rataan $(\mathbf{K g})$ & PBBH (gr) \\
P0 & $1,88^{\mathrm{a}}$ & 62,67 \\
P1 & $3,75^{\mathrm{b}}$ & 125 \\
P2 & $6,25^{\mathrm{c}}$ & 208,3 \\
\hline
\end{tabular}

Sumber: Nizma et al., 2015

Kemudian, hasil analisis sidik ragam menunjukkan bahwa tingkat pemberian temulawak memberikan pengaruh yang sangat nyata $(\mathrm{P}<0,01)$ terhadap pertambahan berat badan baik pada pemeriksaan 15 hari maupun 30 hari. Pertambahan bobot badan pada hari ke 15 yang memberikan pengaruh yang sangat nyata, begitu pula dengan pertambahan berat badan domba di hari ke 30 .

Kandungan dalam temulawak berisi senyawa-senyawa kimia yang memiliki kandungan aktif secara fisiologi, yaitu kurkuminoid dan minyak atsiri. Kandungan kurkuminoid dalam temulawak berfungsi sebagai antibakteria, anti-kanker, anti-tumor, serta mengandung antioksidan. Kandungan kurkuminoid dalam temulawak berkisar 1-2\% dan kandungan minyak atsiri dalam temulawak berkisar 3-12\% (Anand, 2007). Kurkumin berfungsi meningkatkan pencernaan dengan merangsang dinding kantong empedu untuk mengeluarkan cairan empedu dan merangsang keluarnya getah pankreas yang mengandung enzim amilase, lipase dan protease yang berguna untuk meningkatkan pencernaan bahan pakan seperti karbohidrat, lemak dan protein (Tsana, 2017).

\section{Analisa Usaha}

Analisis usaha bertujuan untuk menilai sejauh mana manfaat yang dapat diperoleh dalam menentukan keuntungan usaha dan kelayakan ekonomi, sehingga dapat direkomendasikan atau tidak kepada peternak. Berdasarkan hasil analisis usaha dari ketiga perlakuan, maka dinyatakan bahwa perlakuan P1 mempunyai keuntungan paling besar yaitu Rp1.329.145, untuk selengkapnya dapat dilihat pada Tabel 3.

Tabel 3. Analisis usaha

\begin{tabular}{llr}
\hline \multicolumn{1}{c}{ Analisa } & \multicolumn{1}{c}{ P0 } & P1 \\
Usaha & & \\
\hline Pendapatan (Rp) & 662.945 & 1.329 .145 \\
R/C ratio & 1,083 & 1,163 \\
B/C ratio & 0,083 & 0,163 \\
BEP harga (Rp) & 55.390 & 51.53 \\
BEP produksi & 21,51 & 21,49 \\
(Kg) & \multicolumn{2}{c}{} \\
MBCR & \multicolumn{2}{c}{23,132} \\
\hline
\end{tabular}

Sumber : Data primer diolah 2021

Untuk mengetahui apakah usaha ternak kambing dapat menguntungkan atau tidak, perlu dilakukannya analisis Revenue cost ratio 
( $\mathrm{R} / \mathrm{C}$ ratio). $\mathrm{R} / \mathrm{C}$ ratio dikatakan menguntungkan apabila nilainya lebih dari 1 . Pada Tabel 3, semua perlakuan memiliki nilai lebih dari 1 artinya usaha layak untuk dijalankan.

Selanjutnya pada analisa Break Event Point (BEP), pada BEP harga dapat diartikan bahwa usaha tidak akan untung dan tidak akan rugi pada penjualan sebesar BEP harga, dengan kata lain jika harga jual > BEP harga maka usaha tersebut menguntungkan. Dalam hal ini, jika kambing dijual dengan harga tersebut maka usaha tidak mengalami rugi, tetapi juga belum memperoleh laba.

Titik impas/Break Event Point (BEP) produksi :

BEP produksi P0 $(21,51 \mathrm{~kg})$ sedangkan BEP harga sebesar Rp 55.390/kg, artinya bobot badan kambing P0 hanya akan mendapatkan keuntungan apabila dapat menjual ternaknya dengan harga jual > Rp 55.390/kg/ekor, jika harga jualnya $\mathrm{Rp}$ 60.000/kg/ekor maka produksi yang harus dicapai $>21,51 \mathrm{~kg}$ baru mendapat keuntungan.

BEP produksi P1 (21,49 kg) sedangkan BEP harga sebesar Rp 51.583/kg, artinya bobot badan kambing P1 hanya akan mendapatkan keuntungan apabila dapat menjual ternaknya dengan harga jual > Rp 55.802/kg/ekor, jika harga jualnya $\mathrm{Rp}$ 60.000/kg/ekor maka produksi yang harus dicapai $>21,49 \mathrm{~kg}$ baru mendapat keuntungan.

Marginal Benefit Cost Ratio (MBCR) digunakan untuk mengetahui atau mengukur kelayakan paket teknologi introduksi dalam memberi nilai tambah terhadap teknologi petani, yaitu perbandingan antara keuntungan dan biaya marginal. Perhitungan MBCR menjelaskan kalau nilainya lebih kecil dari 1 berarti teknologi introduksi tidak berpotensi dikembangkan secara ekonomis. Sebaliknya kalau lebih besar dari 1, teknologi tersebut berpotensi dikembangkan secara ekonomis. Dari hasil yang didapatkan nilai MBCR lebih dari satu yaitu sebesar 23,132.

Dari hasil analisis usaha tani maka yang direkomendasikan yaitu perlakuan 1 dengan pemberian tepung temulawak 12 gram $+40 \mathrm{ml}$ air karena dilihat dari analisis usahanya keuntungan, $\mathrm{R} / \mathrm{C}$ ratio, $\mathrm{B} / \mathrm{C}$ ratio yang didapatkan P1 lebih tinggi dibandingkan P0 dan nilai MBCR sebesar 23,132 maka usaha ini berpotensi dikembangkan.

\section{KESIMPULAN DAN SARAN}

Pemberian tepung temulawak $12 \mathrm{gr}+40$ $\mathrm{ml}$ air sebagai pakan tambahan (feed additive) mampu meningkatkan performa ternak kambing yaitu terjadi kenaikan nilai PBBH. Hasil analisis kelayakan usaha tani menunjukkan bahwa pemberian tepung temulawak $12 \mathrm{gr}+40 \mathrm{ml}$ air lebih menguntungkan.

Untuk mendukung peningkatan pengetahuan, sikap dan keterampilan peternak di Kelompok Ternak Mekar Harapan 5 perlu adanya pembinaan dan pendampingan yang lebih baik lagi terkait usaha ternak kambing.

Untuk mendukung pengembangan usaha penggemukan ternak kambing di Kelompok ternak Mekar Harapan 5 Desa Sukaresik perlu adanya tindak lanjut berupa pemanfaatan temulawak terhadap pertambahan bobot badan kambing. Telah diketahui pemberian tepung temulawak dapat memberikan peningkatan 
Pertambahan Bobot Badan Harian (PBBH) dan

secara ekonomi juga menguntungkan sehingga dapat meningkatkan pendapatan peternak kambing.

\section{DAFTAR PUSTAKA}

Anand, P. (2007). Bioavailability of Curcumin: Problems and Promises. $J \mathrm{Mol}$ Pharmaceutics, 4(6): $\quad$ 807-. file:///C:/Users/LENOVO/Downloads/D APUS/Anand, 2007.pdf

Anggorodi. (1985). Ilmu Makanan Ternak Umum. Gramedia.

Boesono, H., Anggoro, S., \& Bambang, N. (2011). Laju Tangkap dan Analisis Usaha Penangkapan Lobster (Panulirus Sp) Dengan Jaring Lobster (Gillnet Monofilament) di Perairan Kabupaten Kebumen. Jurnal Saintek Perikanan, 7(1),77-87. https://doi.org/10.14710/ ijfst.7.1.77-87

Deptan. (2003). Pedoman Umum Pemilihan metode penyuluhan pertanian. Badan Pengembangan SDM Pertanian. http://lib.bppsdmp.pertanian.go.id/main/i ndex.php?p=show_detail\&id=2616

Hartadi, S, R., \& Tillman, A. D. (1991). Tabel Komposisi Bahan Makanan Ternak untuk Indonesia. Universitas Gajah Mada.

Kartika, A. A. . (2017). Pemberian Temulawak (Curcuma Xhanthoriza Roxb) Dan Kunyit (Curcuma Domestic Val) Terhadap Pertambahan Bobot Badan Kambing Peranakan Ettawa Jantan. Universitas Jambi.

Malian, A. H. (2004). Analisis Ekonomi Usahatani dan Kelayakan Finansial Teknologi Pada Skala Pengkajian.

Nizma, A., Humaidah, N., Kes, M., Suryanto, D., \& MP. (2015). Pengaruh Tingkat Pemberian Temulawak (Curcuma xanthorriza) Sebagai Obat Cacing Herbalterhadap Jumlah Telur Cacing Haemonchus contortus dan Pertambahan Berat Badan Domba.
Soekartawi. (2006). Analisis Usaha Tani. UI Press.

Tsana. (2017). Pengaruh Pemberian Tepung Kunyit (Curcuma Domestica Val.) Dalam Ransum Terhadap Kecernaan Serat Kasar Dan Lemak Kasar Pada Domba Lokal Jantan.

Widayati, E., \& Widalestari, Y. (1996). Limbah untuk Pakan Ternak. Trubus Agrisorana. 